\title{
ANALISIS KEBIJAKAN REHABILITASI NARKOTIKA TERHADAP PECANDU DAN KORBAN PENYALAHGUNAAN NARKOTIKA DI BATAM
}

\author{
Junimart Girsang*, Beny K. Simanjuntak** \\ Fakultas Hukum, Universitas Internasional Batam
}

\begin{abstract}
In 2017, the Institute for Criminal Justice Reform (ICJR) found in the Surabaya District Court, the majority of the pleas of the Public Prosecutor for the accused as addicts and victims of narcotics abuse for convicting prison were $90 \%$ (ninety percent) and $10 \%$ (ten percent) are terminated by the imposition of narcotics rehabilitation as an attempted conviction. Therefore, this research was conducted in Batam city as one of the regions with high levels of narcotics illicit trafficking.

The purpose of this study is to find out the procedures for implementing narcotic rehabilitation, to analyze the effectiveness of the law in the application of narcotic rehabilitation for addicts and victims of narcotics abuses in Batam City, and to measure the level of justice in providing penalization for addicts and victims of narcotics abusers processed through court verdicts. This research was carried out by conducting empirical legal research at the Riau Islands Police Narcotics Directorate, BNN Riau Islands Province, Batam District Court, and Batam BNN Rehabilitation Atelier.

Keywords: Effectiveness, Narcotics Rehabilitation, Addicts, Victims of Narcotics Abuse, Batam city
\end{abstract}

\begin{abstract}
Abstrak
Pada tahun 2017, Institute For Criminal Justice Reform (ICJR) menemukan bahwa di Pengadilan Negeri Surabaya mayoritas Jaksa Penuntut Umum menuntut terdakwa sebagai pecandu dan korban penyalahgunaan narkotika dilakukan pemidanaan penjara sebanyak $90 \%$ (sembilan puluh persen), dan sebanyak $10 \%$ (sepuluh persen) yang diputus dengan pengenaan rehabilitasi narkotika sebagai upaya pemidaan. Oleh karena itu, peneliti melakukan penelitian terkait rehabilitasi narkotika di Kota Batam sebagai salah satu wilayah dengan tingkat peredaran gelap narkotika yang tinggi.

Tujuan dari penelitian ini untuk mengetahui tata cara penerapan rehabilitasi narkotika, menganalisis efektivitas hukum dalam penerapan rehabilitasi narkotika, serta mengukur tingkat keadilan dalam memberikan ganjaran hukuman (Vonis) melalui putusan pengadilan. Peneliti melakukan penelitian hukum secara empiris pada Direktorat Narkotika Polda Kepri, BNN Provinsi Kepri, Pengadilan Negeri Batam, dan Loka Rehabilitasi BNN Batam.
\end{abstract}

Kata Kunci: Efektivitas, Rehabilitasi Narkotika, Pecandu, Korban Penyalahgunaan Narkotika, Kota Batam

\footnotetext{
*Alamat Korespondensi : elza@uib.ac.id

** Alamat Korespondensi : beny.simjtk@gmail.com
} 


\section{A. Latar Belakang Masalah}

Dengan diratifikasinya Single Conventions On Narcotic Drugs, 1961 dan Protocol Amending the Single Convention on Narcotic Drugs, 1961 ke dalam UU RI Nomor 8 Tahun 1976 Tentang Pengesahan Konvensi Tunggal Narkotika 1961 Beserta Protokol yang mengubahnya, Pemerintah RI menerbitkan UU RI Nomor 9 Tahun 1976 Tentang Narkotika, dimana pada penjelasan Pasal 33 dan Pasal 34 Undang-undang tersebut menyebutkan aturan terkait Rehabilitasi terhadap pecandu dan pengalahgunaan Narkotika sebagai upaya pendekatan kesehatan melalui putusan Pengadilan. Kemudian, Pemerintah RI menerbitkan UU RI Nomor 35 Tahun 2009 dimana pada pasal 54 UU RI Nomor 35 Tahun 2009 yang berbunyi "Pecandu Narkotika dan korban penyalahgunaan Narkotika wajib menjalani Rehabilitasi medis dan Rehabilitasi sosial"1, menunjukkan bukti bahwa Pemerintah serius dalam melakukan upaya pendekatan kesehatan terhadap pecandu dan korban penyalahgunaan narkotika.

Dengan diterbitkannya undang-undang tersebut, Mahkamah Agung RI mengeluarkan Surat Edaran Mahkamah Agung (SEMA) RI Nomor 04 Tahun 2010 tentang Penempatan Penyalahguna, Korban Penyalahguna, dan Pecandu Narkotika ke dalam Lembaga Rehabilitasi Medis dan Rehabilitasi Sosial terhadap terdakwa yang tertangkap tangan ditemukan barang bukti Narkotika untuk pemakaian 1 (satu) hari pada terdakwa. Namun pada prakteknya, Institute For Criminal Justice Reform (ICJR) menemukan bahwa pada tahun 2017 di Pengadilan Negeri Surabaya terhadap sebanyak 32 putusan terkait kasus terdakwa sebagai pecandu dan korban penyalahgunaan Narkotika, mayoritas tuntutan Jaksa Penuntut Umum (JPU) menuntut dilakukan pemidanaan penjara sebanyak $90 \%$ (sembilan puluh persen), dan hanya sebanyak 10\% (sepuluh persen) yang dituntut dengan pengenaan rehabilitasi narkotika. ${ }^{2}$ Hal tersebut telah mencederaikan apa yang diamanatkan oleh Undang-undang dan apa yang tertulis dalam SEMA No. 4 Tahun 2010.

Tujuan dilakukannya penelitian ini dilakukan untuk mengetahui dan menganalisis efektivitas hukum dalam penerapan kebijakan rehabilitasi Narkotika bagi pecandu dan korban penyalahgunaan Narkotika di Kota Batam, menganalisis tingkat keadilan dalam memberikan ganjaran hukuman terhadap pecandu dan korban penyalahgunaan Narkotika pada Pengadilan Negeri Batam, mengetahui kebijakan hukum yang diambil guna mengoptimalkan rehabilitasi Narkotika bagi pecandu dan korban penyalahgunaan Narkotika khususnya di Kota Batam.

\footnotetext{
${ }^{1}$ Pasal 54 Undang-Undang Nomor 35 Tahun 2009 Tentang Narkotika (Lembaran Negara Republik Indonesia Tahun 2009 Nomor 143).

${ }^{2}$ Institute For Criminal Justice Reform, Hakim Diminta Untuk Memberikan Putusan Rehabilitasi kepada Pengguna dan Pecandu Narkotika Sesuai SEMA 4/2010, 2017, Diambil pada 20 Juli 2018 dari:https://icjr.or.id/hakim-diminta-untuk-memberikan-putusan-rehabilitasi-kepada-penggunadan-pecandu-narkotika-sesuai-sema-42010/
} 


\section{B. Rumusan Masalah}

Dengan tujuan tersebut, maka dalam penelitian ini, peneliti mengangkat beberapa permasalahan yang akan diteliti, yaitu :

1. Bagaimana tata cara penerapan rehabilitasi Narkotika terhadap pecandu dan korban penyalahgunaan Narkotika di Kota Batam ?

2. Bagaimana efektivitas terhadap penerapan kebijakan rehabilitasi Narkotika bagi pecandu dan korban penyalahgunaan Narkotika di Kota Batam ?

\section{Metode Penelitian}

Peter Mahmud Marzuki merumuskan penelitian hukum sebagai suatu proses untuk menemukan aturan hukum, prinsip-prinsip hukum, maupun doktrindoktrin hukum, guna menjawab isu hukum yang dihadapi. ${ }^{3}$ Penelitian hukum juga berperan sebagai pemecahan masalah (problem solving). Dalam rangka pemecahan masalah, maka salah satu prinsip utama adalah mencari penyebab masalah karena hanya dengan mengetahui apa penyebab permasalahan tersebut, maka permasalahan tersebut harus dapat dipecahkan atau diatasi. ${ }^{4}$ Sehingga pentingnya membuat suatu rancangan penelitian, guna menetapkan alur atau langkah-langkah yang dilakukan dalam penelitian ini, dan diharapkan dapat mencapai apa yang menjadi tujuan dari penelitian tersebut.

Berkaitan dengan penelitian hukum, Soerjono Soekanto membagi penelitian hukum itu menjadi 2 (dua) penelitian hukum, yaitu Penelitian Hukum Normatif, dan Penelitian Hukum Sosiologis atau Empiris. ${ }^{5}$ Dalam melakukan penelitian ini, peneliti memutuskan untuk melakukan penelitian hukum empiris, guna memperoleh gambaran (deskripsi) yang lengkap tentang keadaan hukum yang berlaku ditempat tertentu dan pada saat tertentu, dalam hal ini di Kota Batam, serta untuk mengetahui gejala yuridis yang ada, atau peristiwa hukum yang terjadi dalam masyarakat Kota Batam. ${ }^{6}$ Dalam menentukan objek penelitian, metode penelitian dengan teknik purposive sampling dengan menentukan penelitian pada Direktorat Narkotika Polda Kepri sebagai tempat penyidikan perkara Narkotika, BNN Provinsi Kepri yang melakukan penyidikan tindak pidana narkotika dan juga menaungi Tim Asesmen Terpadu (TAT) dalam melakukan Asesmen terhadap pecandu dan penyalahguna Narkotika, serta Pengadilan Negeri Batam (Hakim) sebagai tempat dalam memutuskan atau menetapkan Rehabilitasi Narkotika terhadap terdakwa sebagai pecandu dan korban penyalahgunaan Narkotika. Disamping itu, peneliti juga menentukan objek penelitian pada Loka Rehabilitasi Narkotika BNN Batam, dimana Loka Rehabilitasi merupakan tempat untuk melakukan rehabilitasi Narkotika sebagai upaya penulihan kesehatan. Sehingga

\footnotetext{
${ }^{3}$ Peter Mahmud Marzuki, Penelitian Hukum, Cet.2, Jakarta : Kencana, 2008, hlm. 29

${ }^{4}$ Syahruddin Nawawi, Penelitian Hukum Normative Versus Penelitian Hukum Empiris, Makassar: Umitoha Ukhuwah Grafika, 2017, hlm. 41

${ }^{5}$ Soerjono Soekanto, Pengantar Penelitian Hukum, Jakarta: UI Press, 1986, hlm. 54.

${ }^{6}$ Abdulkadir Muhammad, Hukum dan Penelitian Hukum, Bandung : PT. Citra Aditya Bakti, 2004, hlm.50.
} 
dinilai penting untuk pengambilan data terhadap narasumber yang ditentukan, dan melakukan wawancara secara tidak terstruktur terhadap narasumber tersebut.

Bambang Sunggono menegaskan bahwa suatu penelitian tidak dapat berlangsung dengan benar kalau tidak memanifestasikan penalaran yang benar dan memanifestasikan ketaatan yang benar pada hukum-hukum logika, ${ }^{7}$ sehingga penelitian dengan menggunakan metode analisis kualitatif dinilai tepat dalam melakukan penelitian ini. Penelitian kualitatif adalah penelitian yang bermaksud untuk memahami fenomena tentang apa yang dialami oleh subyek penelitian misalnya perilaku, persepsi, motivasi, tindakan dan lain-lain secara holistik dan dengan cara deskripsi. Data deskriptif yang dihasilkan berupa kata-kata tertulis atau lisan dari orang-orang dan perilaku yang diamati. ${ }^{8}$

\section{Hasil Penelitian Dan Pembahasan}

Tata cara penerapan rehabilitasi Narkotika terhadap pecandu dan korban penyalahgunaan Narkotika di Kota Batam

Dalam melakukan wawancara terhadap salah satu penyidik pada Direktorat Reserse Narkotika Polda Kepri yang menangani perkara Narkotika, didapatkan data pertahun perkara Narkotika yang ditangani Polda Kepri beserta jajarannya yaitu sebagai berikut :

Tabel 1. Data Perkara Narkotika Tahun 2015 s/d 2018

\begin{tabular}{|l|l|l|l|l|}
\hline & $\mathbf{2 0 1 5}$ & $\mathbf{2 0 1 6}$ & $\mathbf{2 0 1 7}$ & $\mathbf{2 0 1 8}$ \\
\hline Ditnarkotika Polda Kepri & 104 & 101 & 82 & 106 \\
\hline Polresta Barelang & 213 & 188 & 130 & 142 \\
\hline Polresta Tg. Pinang & 51 & 65 & 51 & 70 \\
\hline Polres Karimun & 64 & 86 & 56 & 59 \\
\hline Polres Bintan & 15 & 23 & 30 & 26 \\
\hline Polres Natuna & 7 & 13 & 3 & 16 \\
\hline Polres Lingga & 3 & 2 & 3 & 8 \\
\hline
\end{tabular}

\section{Sumber : Polda Kepri beserta Jajarannya}

Dengan tingginya perkara Narkotika di Provinsi Kepri, sehingga adanya penekanan dari pimpinan Polri terhadap penyelidik dan penyidik Kepolisian untuk mencari informasi, dan melakukan penangkapan terhadap terduga pelaku tindak pidana Narkotika yang tanpa izin menguasai, menyimpan dan memiliki Narkotika diatas jumlah barang bukti sebagaimana ditetapkan didalam SEMA Nomor 04 Tahun 2010 terkait batasan barang bukti Narkotika, sehingga diharapkan dalam penyidikannya dapat dilanjutkan ke proses peradilan umum. Namun, untuk tersangka yang tertangkap tangan yang memiliki barang bukti dibawah aturan SEMA Nomor 04 Tahun 2010, penyidik akan mencari fakta, apakah tersangka tersebut merupakan pengedar atau kurir (perantara), atau hanya merupakan

${ }^{7}$ Bambang Sunggono, Metodologi Penelitian Hukum, Cet. 1, Jakarta : PT.Raja Grafindo Persada, 2007, hlm. 9.

${ }^{8}$ Lexy J Moleong, Metodologi Penelitian Kualitatif, Bandung: Remaja Rosda Karya, 2002, hlm. 4 
penyalahguna Narkotika. Apabila tersangka tersebut merupakan hanya penyalahguna Narkotika, penyidik akan meminta kepada Tim Asesmen Terpadu (TAT) BNNP Kepri untuk dilakukan Asesmen, agar dapat dilakukan rehabilitasi Narkotika sebagai upaya pendekatan kesehatan. Peneliti juga melakukan wawancara terhadap salah satu pemyidik pembantu pada Satnarkotika Polresta Barelang, dan meminta identitasnya dirahasiakan dan tidak mau disebutkan dalam penelitian ini, bahwa terhadap tersangka yang tertangkap yang tidak memiliki barang bukti Narkotika, namun pada saat dilakukan cek urine menunjukkan bahwa tersangka tersebut positif menggunakan Narkotika. Penyelidik atau penyidik dapat melakukan bargaining (tawar menawar) terhadap tersangka karena adanya faktor $\mathrm{X}$ bagi penyelidik atau penyidik. Sedangkan berdasarkan ketentuan yang terdapat didalam Pasal 103 ayat (1) huruf b UU RI No. 35 Tahun 2009, bahwa terhadap tersangka yang tidak terbukti bersalah menurut pasal tersebut dilakukan proses hukum sampai ke pengadilan untuk mendapatkan penetapan rehabilitasi narkotika. Namun tersangka lebih memilih faktor $\mathrm{X}$ tersebut. Faktor $\mathrm{X}$ yang dimaksud disni dapat berupa materi atau dapat juga berupa sebuah informasi untuk memberikan informasi terkait peredaran gelap Narkotika. Dengan situasi seperti dimaksud diatas, faktanya bahwa banyak masyarakat lebih memilih factor $\mathrm{X}$ tersebut agar dapat lepas dari proses atau jerat hukum. Kemudian, narasumber tersebut juga menjelaskan bahwa penyidik dalam melakukan penyidikan terhadap tersangka sebagai penyalahguna yang tertangkap tangan memiliki barang bukti dibawah batasan barang bukti pemakaian 1 (satu) hari sebagaimana diatur didalam pada SEMA Nomor 4 Tahun 2010, bahwa pada saat proses penyidikan, penyidik memiliki kewenangan untuk meminta secara tertulis kepada Tim Asesmen Terpadu (TAT) agar dilakukan Asesmen terhadap tersangka untuk mendapatkan Surat Rekomendasi dapat dilakukannya rehabilitasi Narkotika. Dalam hal ini, penyidik juga dapat melakukan bargaining terhadap tersangka ataupun dengan keluarga tersangka, karena pihak tersangka lebih memilih dilakukan rehabilitasi Narkotika dari pada pemidanaan penjara.

Kemudian, narasumber tersebut juga menjelaskan bahwa dalam pemberantasan narkotika, hal yang sangat dituntut dalam pembuktian sebagai penyalahguna narkotika adalah unsur memiliki dan menguasai untuk menetapkan tersangka sebagai penyalahguna narkotika. Unsur memiliki disini, seorang tersangka tersebut harus menguasai barang bukti narkotika, sehingga dengan kekuasaannya tersebut, tidak memungkinkan ada orang lain yang dapat mengambilnya. Sebagai contoh, seseorang yang menyimpan barang bukti tidak didalam badannya atau tidak didalam rumahnya (penguasaannya), namun barang bukti tersebut disimpan diluar rumah yang tidak memiliki perkarangan tertutup (tidak memiliki pagar), sehingga setiap orang dengan bebas dapat mengakses tempat tersebut. Disini, Penyelidik yang menemukan barang bukti yang berada dipekarangan rumah si pemilik rumah, tidak dapat langsung menuduh si pemilik rumah merupakan pemilik barang bukti narkotika tersebut. Hal inilah yang menyulitkan penyelidik untuk membuktikan bahwa si pemilik rumah adalah sebagai pemilik barang bukti yang disimpan diluar di pekarangan rumah terbuka tersebut. 
Narasumber juga menjelaskan bahwa masyarakat kita yang memiliki ekonomi rendah, sehingga sering ikut membantu secara tidak langsung peredaran gelap narkotika. Sebagai contoh di Kampung Aceh yang berada di Simpang Dam Kota Batam, bahwa setiap penyelidik Kepolisian yang masuk ke wilayah tersebut, akan sulit mendapatkan informasi melalui masyarakat disekitar kampung aceh tersebut, meskipun warga tersebut tidak terlibat secara langsung melakukan kegiatan peredaran gelap narkotika sehingga memiliki kesan yang menutupi kegiatan peredaran gelap narkotika diwilayah tersebut. Hal ini dapat dilihat bahwa masyarakat yang berdomisili diwilayah kampung aceh tersebut dalam mencari rejeki dari penyediaan tempat parkir, penyewaan kamar kos yang biasa digunakan oleh pengedar narkotika, warung sembako, dan lain sebagainya untuk kebutuhan warga di kampung aceh tersebut. Sehingga, wilayah tersebut sangat tertutup bagi warga luar yang baru atau warga yang tidak dikenal masuk ke lingkungan tersebut.

Peneliti juga melakukan wawancara dengan Kabid Rehabilitasi BNNP Kepri dan juga merupakan salah satu Tim Asesmen Terpadu (TAT) pada BNNP Kepri, menjelaskan terkait tugas dan wewenang dari Badan Narkotika Nasional sebagaimana diatur didalam UU RI Nomor 35 tahun 2009 tentang narkotika. Dalam melakukan wawancara tersebut, dijelaskan bahwa dalam melakukan Rehabilitasi terhadap pecandu dan korban penyalahgunaan Narkotika, Rehabilitasi Narkotika dapat dilakukan dengan cara :

Rehabilitasi secara sukarela (Voluntary) atau dikenal dengan istilah 'wajib lapor' dalam UU RI Nomor 35 tahun 2009 tentang narkotika.

Rehabilitasi Narkotika secara sukarela (Voluntary) atau dikenal dengan istilah 'wajib lapor' diatur dalam pasal 55 UU RI Nomor 35 Tahun 2009, dituliskan bahwa Orang tua atau wali dari pecandu Narkotika, baik yang belum cukup umur maupun yang sudah cukup umur, wajib melaporkan diri atau dilaporkan oleh keluarganya kepada pusat kesehatan masyarakat, rumah sakit, dan/atau lembaga rehabilitasi medis dan rehabilitasi sosial yang ditunjuk oleh Pemerintah untuk mendapatkan pengobatan dan/ atau perawatan melalui rehabilitasi medis dan rehabilitasi sosial. ${ }^{9}$ Dengan adanya aturan terkait wajib lapor tersebut, diharapkan adanya peran serta dari orang tua atau wali atau keluarga untuk aktif melaporkan pecandu dan korban penyalahguna ke lembara rehabilitasi narkotika guna dilakukan upaya pemulihan kesehatan sebelum ditangkap atau tertangkap tangan, dan demi melindungi orang tua atau wali dari pecandu Narkotika dari jeratan hukum, serta mewajibkan masyarakat ikut berpartisipasi terhadap program pemerintah untuk memberantas peredaran gelap Narkotika. Tata cara pelaksanaan 'wajib lapor' diatur dalam Peraturan Pemerintah RI Nomor 25 Tahun 2011 Tentang Pelaksanaan Wajib Lapor Pecandu Narkotika. Untuk itu, setiap pelaksanaan rehabilitasi secara sukarela yang dilakukan oleh institusi penerima wajib lapor (IPWL) yang telah ditunjuk oleh Pemerintah, wajib mempedomani Peraturan Pemerintah tersebut. Namun, sebelum dilakukannya rehabilitasi narkotika, setiap calon residen (pasien) wajib dilakukan

9 Pasal 55 ayat (1) dan ayat (2) Undang-undang Nomor 35 Tahun 2009 Tentang Narkotika (Lembaran Negara Tahun 2009 Nomor 143). 
Asesmen oleh Tim Asesmen Terpadu (TAT) untuk menentukan tingkat keparahan kecanduan calon residen (pasien) tersebut dan dapat menentukan langkah selanjutnya dalam menangani calon residen tersebut.

Berikut ini digambarkan diagram alur tata cara penerapan rehabilitasi narkotika dengan sukarela (Voluntary) atau wajib lapor berdasarkan Peraturan Pemerintah Nomor 25 Tahun 2011 Tentang Pelaksanaan Wajib Lapor Pecandu Narkotika.

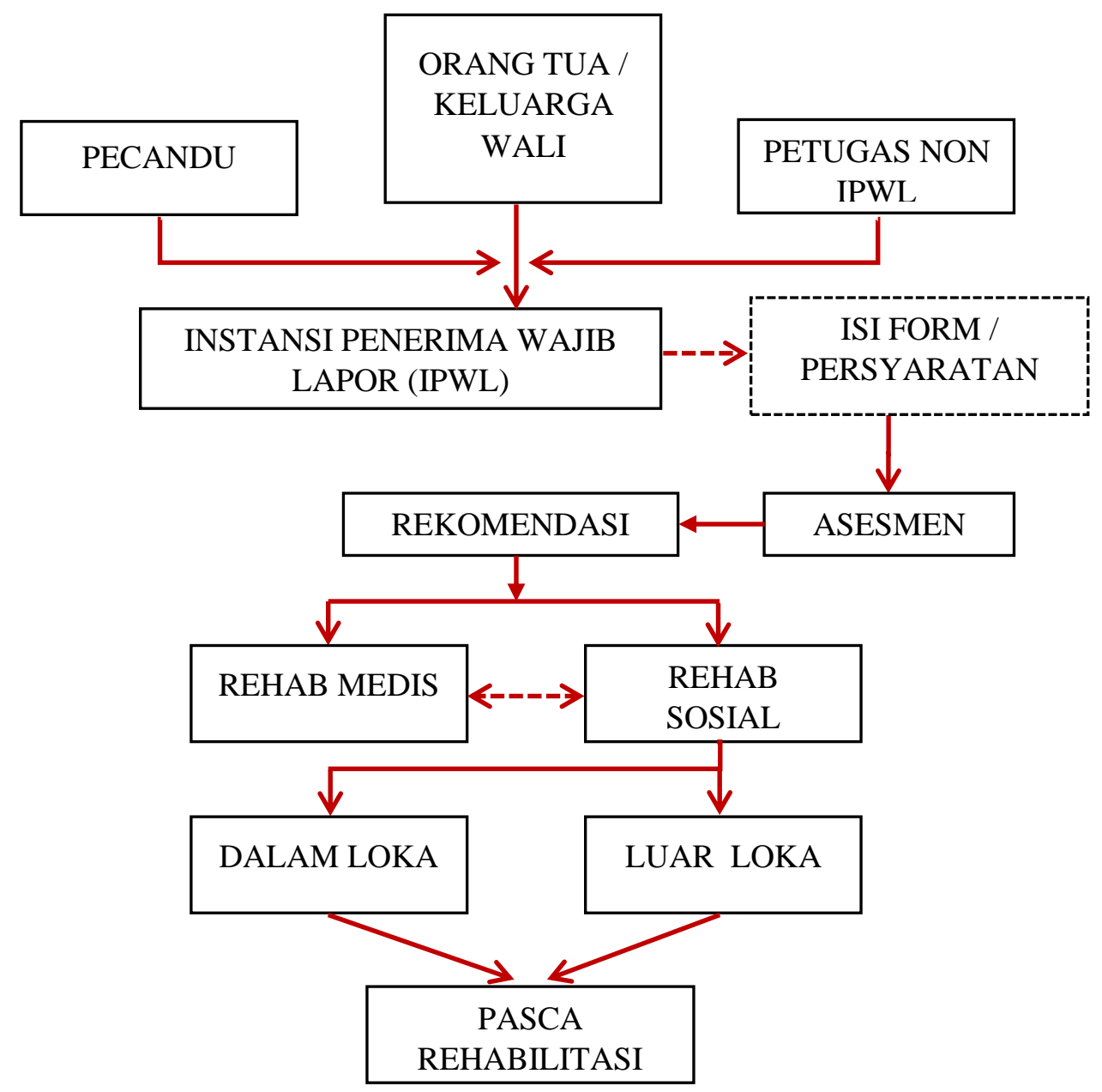

Gambar 1. Diagram Alur Tata Cara Rehabilitasi Narkotika Secara Sukarela berdasarkan data dari BNNP Kepri dan Loka Rehabilitasi BNN Batam, dan peraturan perundang-undangan.

Rehabilitasi Narkotika yang dilakukan terhadap tersangka/ atau terdakwa melalui proses hukum (Compulsary).

Penetapan rehabilitasi narkotika melalui proses hukum (Compulsary) dilakukan karena tertangkapnya seseorang penyalahguna Narkotika atau korban penyalahguna narkotika yang sedang menggunakan, membawa, menyimpan atau menggunakan Narkotika (dalam penguasaan tersangka). Berdasarkan pasal 3 ayat (1) Peraturan Kepala BNN Nomor 11 Tahun 2014, rehabilitasi Narkotika juga dapat 
dilakukan terhadap tersangka yang pada saat sedang dalam proses penyidikan di Kepolisian maupun dalam penyidikan pada BNN, karena melihat tingkat dari keparahan kecanduan tersangka tersebut, dan sehingga tidak dimungkinkan untuk dilakukannya proses penyidikan, maka diharuskan untuk dilakukan upaya pemulihan kesehatan terlebih dahulu, dan kemudian baru dilanjutnya pada proses hokum untuk mendapatkan penetapan atau putusan dari Hakim. Hal ini sesuai dengan pasal 103 Ayat 1 UU RI Nomor 35 Tahun 2009 Tentang Narkotika.

Dalam pasal 127 ayat (2) UU RI Nomor 35 Tahun 2009 juga meyebutkan bahwa dalam memutuskan perkara narkotika, hakim wajib mempertimbangkan untuk memutuskan rehabilitasi narkotika terhadap pecandu dan korban penyalahgunaan narkotika. Namun, wajib hukumnya untuk dilakukan Asesmen oleh Tim Asesmen Terpadu (TAT), untuk mendapatkan Surat Rekomendasi.

dilihat dalam Surat Edaran Mahkamah Agung Nomor 4 Tahun 2010 terkait jumlah barang bukti untuk pemakaian 1 (satu) hari yang ditemukan pada tersangka, apabila tidak terbukti terdakwa terlibat dalam peredaran gelap narkotika, terhadap terdakwa yang menjalani persidangan pada pengadilan, ditetapkan atau diputuskan untuk dilakukan rehabilitasi narkotika sebagaimana diatur dalam pasal 103 huruf a dan b UU RI Nomor 35 Tahun 2009. Namun, pada prakteknya, bahwa tidak semua tersangka ataupun terdakwa dilakukan rehabilitasi narkotika. Dan terhadap tersangka atau terdakwa sering dikenakan persangkaan pasal 112 Undang-undang Nomor 35 Tahun 2009 untuk menjerat tersangka atau terdakwa agar dilakukan pemidanaan. mBerikut ini digambarkan diagram alur penerapan rehabilasi narkotika melalui proses hukum (Compulsary), berdasarkan Peraturan Pemerintah Nomor 25 Tahun 2011 Tentang Pelaksanaan Wajib Lapor Pecandu Narkotika.

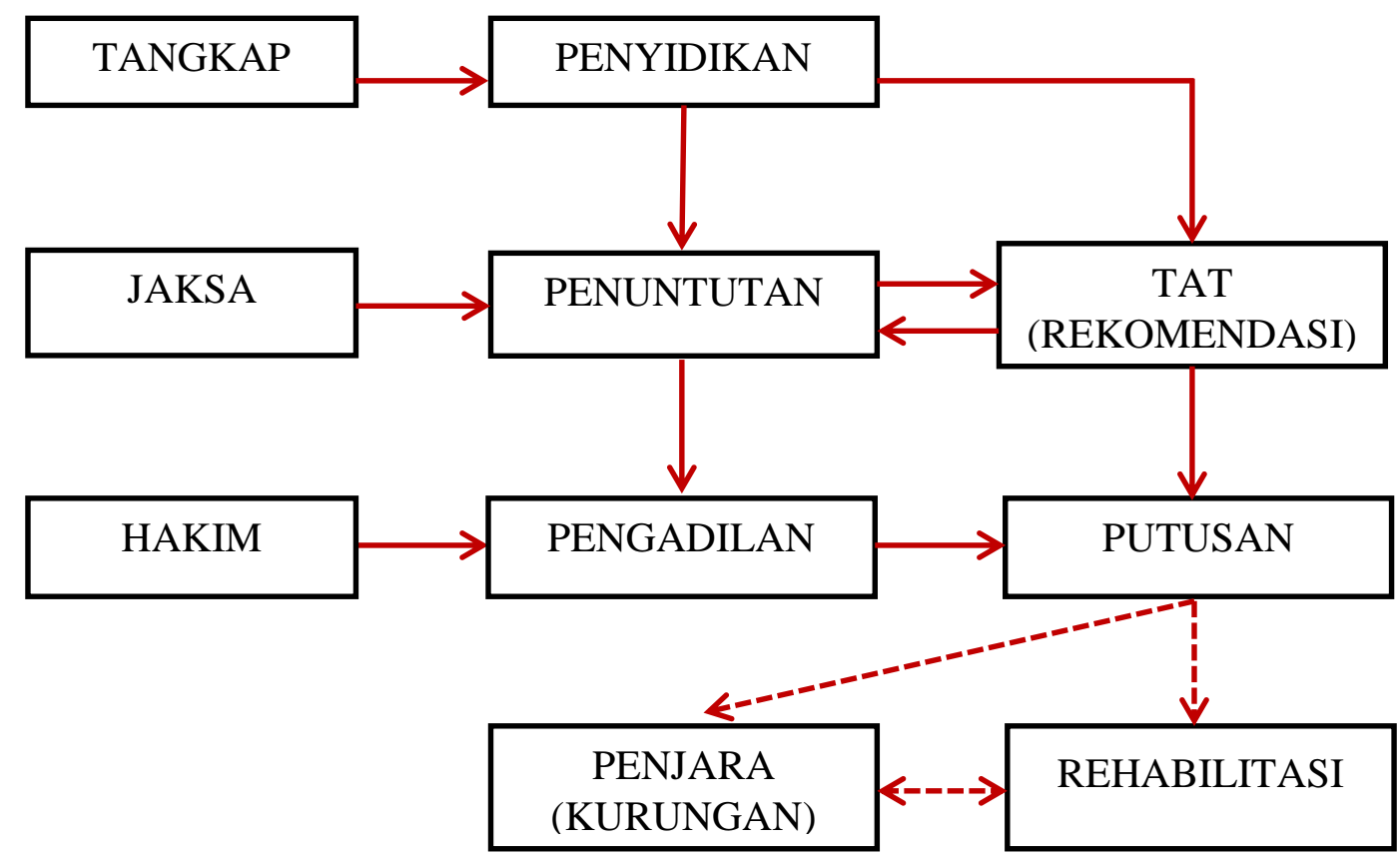


Gambar 2. Diagram Alur Tata Cara Rehabilitasi Narkotika Melalui Upaya Hukum (Compulsary) berdasarkan data dari BNNP Kepri dan peraturan perundangundangan

Peneliti melakukan wawancara terhadap salah satu petugas pada IPWL (Institusi Penerima Wajib Lapor) pada Loka Rehabilitasi BNN Batam, yaitu dengan dr. Danu Cahyono selaku Kepala Loka Rehabilitasi BNN Batam yang menangani pasien pecandu dan korban penyalahgunaan Narkotika. Bahwa Loka Rehabilitasi BNN Batam sifatnya hanya menerima calon residen (pasien) untuk dilakukan rehabilitasi narkotika, baik secara sukarela (voluntary) maupun melalui putusan pengadilan (compulsory), baik melalui putusan Pengadilan Negeri Batam atau Putusan Pengadilan Negeri pada daerah lainnya. Dalam hal ini, Loka rehabilitasi BNN Batam tidak hanya merawat pasien yang merupakan warga Batam atau Kepulauan Riau saja, namun dapat merawat pasien yang berasal dari provinsi lain. Dalam setiap putusan Pengadilan yang memutuskan atau menetapkan terhadap terdakwa untuk dilakukan rehabilitasi narkotika, dalam putusannya wajib disebutkan tempat dilakukannya rehabilitasi narkotika, dan lamanya dilakukan proses rehabilitasi narkotika. Hal ini sesuai dengan Point nomor 3 SEMA No. 4 Tahun 2010.

Peneliti mendapatkan data jumlah residen pada Loka Rehabilitasi Narkotika BNN Batam, yaitu :

Tahun 2014 sebanyak 20 (dua puluh) orang rehabilitasi yang dilakukan rehabilitasi secara sukarela, dan sebanyak 12 (dua belas) orang yang dilakukan melalui upaya Hukum (Compulsary).

Tahun 2015 sebanyak 202 (dua ratus dua) orang rehabilitasi yang dilakukan rehabilitasi secara sukarela, dan sebanyak 21 (dua puluh satu) orang yang dilakukan melalui upaya hukum (Compulsary).

Tahun 2016 sebanyak 325 (tiga ratus dua puluh lima) orang yang dilakukan rehabilitasi secara sukarela, dan sebanyak 20 (dua puluh) orang yang dilakukan rehabilitasi melalui upaya hukum (Compulsary).

Tahun 2017 sebanyak 196 (seratus Sembilan puluh enam) orang yang dilakukan rehabilitasi secara sukarela, dan sebanyak 5 (lima) orang yang dilakukan rehabilitasi melalui upaya hukum (Compulsary).

Tahun 2018 sebanyak 221 (dua ratus dua puluh satu) orang yang dilakukan rehabilitasi secara sukarela, dan sebanyak 2 (dua) orang yang dilakukan rehabilitasi melalui upaya hukum (Compulsary). 


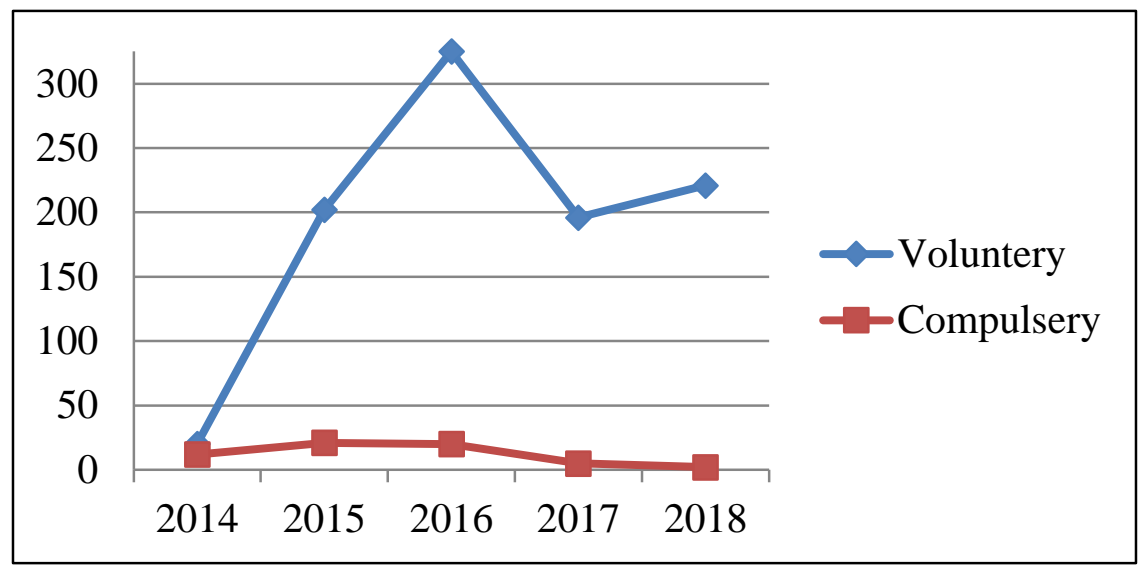

Berikut ini peneliti gambarkan grafik jumlah pasien pecandu dan korban penyalahgunaan Narkotika yang dilakukan rehabilitasi pada Loka Rehabilitasi BNN Batam, baik secara Sukarela (Voluntary) atau wajib lapor, dan melalui upaya hukum (Compulsary) :

Tabel 2. Data Pasien Rehabilitasi Narkotika Tahun 2014 s/d 2018 pada Loka Rehabilitasi BNN Batam.

Dari data tersebut dapat dilihat bahwa terjadinya penurunan jumlah residen Rehabilitasi Narkotika melalui putusan pengadilan dibandingkan tahun sebelumnya, sedangkan jumlah perkara tindak pidana Narkotika sebagai pecandu dan korban penyalahgunaan narkotika cukup signifikan dari tahun ke tahun. Lantas, apa yang menyebabkan jumlah rehabilitasi narkotika yang berdasarkan putusan pengadilan semakin menurun ? dr. Danu Cahyono juga menerangkan bahwa ada beberapa perkara tindak pidana narkotika, dimana terhadap terdakwa yang dikenakan pasal penyalahguna narkotika berdasarkan pasal 127 Undang-undang Nomor 35 Tahun 2009, dan telah mendapatkan surat rekomendasi dari Tim Asesmen Terpadu (TAT), namun Pengadilan menjatuhkan vonis pidana kurungan atau penjara. Terhadap hal ini, dr. Danu Cahyono tidak dapat memberikan penjelasan, karena hal tersebut merupakan penilaian dari hakim yang memimpin persidangan. Hakim memiliki kewenangan dalam memutuskan perkara, dan setiap hakim memiliki alasan tertentu mengapa terhadap penyalahguna dikenakan pemidanaan, bukan dilakukan upaya pemulihan kesehatan.

dr. Danu Cahyono juga menjelaskan bahwa tidak ada langkah hukum atau kebijakan hukum yang diambil untuk mengoptimalkan penerapan rehabilitasi tersebut di Kota Batam sebagai upaya pemulihan kesehatan. Namun ada kebijakan hukum secara nasional yang diambil oleh para pemangku jabatan, yakni Peraturan Bersama Ketua Mahkamah Agung Republik Indonesia, Menteri Hukum dan Hak Asasi Manusia Republik Indonesia, Menteri Kesehatan Republik Indonesia, Menteri Sosial Republik Indonesia, Jaksa Agung Republik Indonesia, Kepala Kepolisian Negara Republik Indonesia, Kepala Badan Narkotika Nasional Republik Indonesia. 
Dalam melakukan wawancara terhadap narasumber yang merupakan salah satu Hakim pada Pengadilan Negeri Batam yaitu TAUFIK ABDUL HALIM NAINGGOLAN, S.H, yang juga menjabat selaku pejabat bidang Humas Pengadilan Negeri Batam, peneliti mendapatkan sumber data jumlah perkara narkotika yang masuk ke Pengadilan Negeri Batam, yaitu :

Tahun 2016 sebanyak 413 perkara;

Tahun 2017 sebanyak 373 perkara;

Tahun 2018 sebanyak 344 perkara.

Dengan data yang didapat tersebut, peneliti menggambarkan dengan grafik jumlah perkara tindak pidana Narkotika pada Pengadilan Negeri Batam :

Tabel 3. Data Perkara NarkotikaTahun 2016 s/d 2018 Yang Masuk Pada Pengadilan Negeri Batam

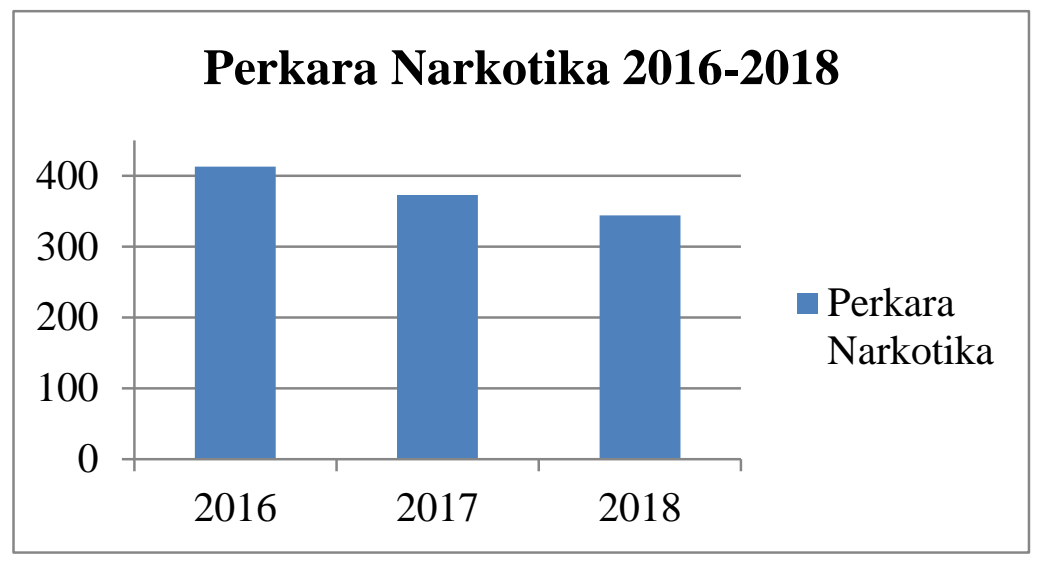

Dari data perkara Narkotika tersebut, Pengadilan Negeri Batam tidak secara khusus merincikan secara terpisah jumlah perkara tindak pidana Narkotika yang diputuskan bersalah sebagai pengedar, perantara, penyalahguna dan korban penyalahgunaan Narkotika, sehingga tidak tergambarkan jumlah terdakwa yang ditetapkan atau diputuskan untuk dilakukan rehabilitasi Narkotika.

Taufik Abdul Halim Nainggolan, S.H juga menjelaskan bahwa setiap putusan terhadap terdakwa tindak pidana Narkotika, Hakim dapat berpedoman pada jumlah barang bukti yang telah diatur didalam SEMA Nomor 04 Tahun 2010, namun setiap Hakim dalam memutuskan perkara harus bersifat mandiri, tanpa ada intervensi atau pengaruh dari pihak manapun. Terhadap putusan hakim yang memutuskan untuk dilakukan Rehabilitasi Narkotika, dalam amar putusannya disebutkan secara jelas tempat rehabilitasi yang terdekat dengan Pengadilan, dan lamanya dilakukan rehabilitasi. Hal ini sesuai dengan angka 3 SEMA Nomor 4 Tahun 2010.

Terkait data sekunder yang didapatkan oleh peneliti, yaitu putusan pengadilan negeri Batam yang didapatkan oleh peneliti, yaitu : 
Perkara nomor : 157/Pid.B/2015/PN.BTM terdakwa atas nama HAMDAN SYUHADA SARAGIH Alias GELENG Bin M. Abdul Halim SARAGIH yang terbukti bersalah dikenakan pasal 127 ayat (1) huruf a UU RI Nomor 35 Tahun 2009 Tentang Narkotika, memiliki barang bukti Narkotika golongan I jenis Shabu

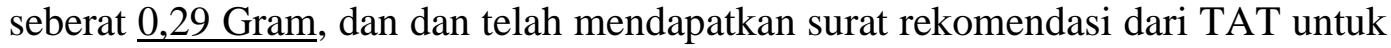
dilakukannya rehabilitasi narkotika, dan terhadap terdakwa dipidana penjara selama 1 (satu) tahun dan rehabilitasi selama 6 (enam) bulan Rehabilitasi di Loka Rehabilitasi BNN Batam.

Perkara nomor : 566/Pid.B/2014/PN.BTM terdakwa CANG KENG HUA Alias AHU yang terbukti bersalah dikenakan Pasal 127 Ayat (1) huruf a UU RI Nomor 35 Tahun 2009 Tentang Narkotika, dengan memiliki barang bukti sebanyak 1 (satu) butir Narkotika Golongan jenis Ekstasi warna merah jambu dengan kode B29 dengan berat 0,39 gram. Terdakwa tidak mendapatkan surat rekomendasi dari TAT untuk dilakukannya rehabilitasi narkotika, sehingga terhadap terdakwa diputuskan divonis 3 (tiga) bulan dengan pidana penjara.

Putusan perkara pada tingkat kasasi Nomor 2158/Pid.sus/2015 terdakwa 1 atas nama Muhammad Agus Salim bin Abdul Karim dan terdakwa 2 atas nama Ahmad Yusuf bin Yusuf, diputuskan bersalah melakukan tindak pidana Penyalahguna Narkotika bagi diri Sendiri dikenakan Pasal 127 Ayat (1) huruf a UU RI Nomor 35 Tahun 2009 Tentang Narkotika karena memiliki barang bukti sebanyak 1 (satu) bungkus Narkotika Golongan I Jenis Shabu dengan berat 0,6 gram, dan terhadap terdakwa tidak mendapatkan surat rekomendasi dari TAT untuk dilakukannya rehabilitasi narkotika, dan terhadap terhadap terdakwa 1 Muhammad Agus Salim bin Abdul Karim divonis penjara selama 1 (satu) tahun, dan terdakwa 2 Ahmad Yusuf bin Yusuf divonis penjara selama 6 (enam) bulan.

Adanya perbedaan putusan perkara tersebut, Hakim Taufik Abdul Halim Nainggolan, S.H menjelaskan bahwa adanya perbedaan putusan untuk dilakukannya rehabilitasi narkotika terhadap terdakwa dikarenakan hakim melihat adanya Surat Rekomendasi dari TAT untuk dilakukannya rehablitiasi medis, dan yang melatarbelakangi perbedaan setiap putusan tersebut adalah keyakinan masingmasing Hakim yang memeriksa perkara dalam persidangan. Setiap Hakim dalam memutuskan perkara, harus bersifat mandiri, sehingga bersifat bebas dalam menafsirkan dan menerapkan SEMA tersebut. Terhadap terdakwa penyalahguna Narkotika yang merasa vonis yang tidak adil, maka terdakwa dapat melakukan banding ke tingkat Pengadilan Tinggi, dan kasasi pada Mahkamah Agung RI.

Peneliti juga melakukan wawancara terhadap salah satu petugas pada Pengadilan Negeri Batam yang tidak ingin disebutkan namanya dalam penelitian ini, bahwa terhadap perkara Narkotika yang merupakan penyalahguna narkotika yang telah mendapatkan Surat Rekomendasi dari Tim Asesmen Terpadu, dapat dilakukannya bargaining (tawar menawar) karena adanya factor $\mathrm{X}$ terhadap vonis hukuman, apakah terhadap terdakwa diputuskan untuk dilakukannya rehabilitasi Narkotika, atau terhadap terdakwa divonis hukuman kurungan atau pidana penjara. Dan lamanya vonis hukuman juga dapat dilakukan bargaining (tawar menawar) karena 
adanya faktor $\mathrm{X}$ yang dapat mempenggaruhi berat ringannya vonis hukuman. Hal tersebut sering dilakukan, karena setiap terdakwa penyalahguna Narkotika, tidak ingin mendapatkan hukuman penjara, atau tidak ingin mendapatkan pemidanaan yang lama ke dalam Lembaga Permasyarakatan. Dan, terhadap perkara tindak pidana penyalahguna narkotika yang belum mendapatkan Surat Rekomendasi untuk dilakukannya Rehabilitasi Narkotika terhadap terdakwa, Hakim dapat meminta secara tertulis kepada TAT (Tim Asesmen Terpadu) untuk dilakukannya Rehabilitasi Narkotika terhadap terdakwa. Namun, sekali lagi disini sering disebutkan bahwa adanya faktor X yang dapat menentukan arah dari putusan hakim terhadap terdakwa penyalahguna maupun korban penyalahguna narkotika.

\section{Efektivitas terhadap penerapan kebijakan rehabilitasi Narkotika bagi pecandu dan korban penyalahgunaan Narkotika di Kota Batam}

Berdasarkan Teori efektivitas hukum menurut Soerjono Soekanto tersebut, peneliti menyimpulkan bahwa penerapan kebijakan rehabilitasi terhadap pecandu dan korban penyalahgunaan Narkotika di Batam tidak efektif. Tidak efektifnya penerapan kebijakan rehabilitasi terhadap pecandu dan korban penyalahgunaan Narkotika di Kota Batam berdasarkan penelitian ini :

\section{1) Faktor hukum itu sendiri (Undang-undang):}

Menurut Achmad Ali, faktor-faktor yang mengukur ketaatan terhadap hukum, bahwa salah satu syarat-syarat dalam membuat suatu undang-undang, seyogyanya aturan tersebut bersifat melarang (prohibitur), dan jangan bersifat mengharuskan (mandatur), sebab hukum yang bersifat melarang (prohibitur) lebih mudah dilaksanakan ketimbang hukum yang bersifat mengharuskan (mandatur). Pada pasal 54 UU RI Nomor 35 Tahun 2009 adalah bersifat mandatur, yaitu mewajibkan pecandu dan korban penyalahguna narkotika untuk dilakukan rehabilitasi, namun pasal 112 merupakan pasal karet yang dapat menjerat pidana bagi penyalahguna narkotika, dan pada Pasal 127 merupakan aturan yang menjelaskan bahwa hakim dalam memutuskan perkara terdakwa sebagai pecandu dan korban penyalahguna narkotika harus memperhatikan pasal-pasal yang mengatur terkait rehabilitasi narkotika. Dengan adanya inkonsistensi pengaturan terkait rehabilitasi Narkotika tersebut, menjadikan ruang bagi penegak hukum (Penyidik, penuntut dan Hakim) dalam menginterpretasikan maksud dalam pasal tersebut, sehingga Faktor hukum dalam mengukur efektivitas hukum berjalan tidak efektif.

Dan kemudian, SEMA Nomor 04 Tahun 2010, pada Angka nomor 2 disebutkan bahwa klasifikasi terdakwa yang dapat dijatuhkan pidana berdasarkan jumlah barang bukti Narkotika untuk pemakaian 1 (satu) hari pada terdakwa yang tertangkap tangan. Hal ini tidak sinkron dengan Undang-undang Nomor 35 Tahun 2009 Tentang Narkotika, dimana dalam undang-undang tersebut tidak disebutkan batasan atau jumlah barang bukti yang ditemukan pada tersangka atau terdakwa yang tertangkap tangan. Sehingga, dalam penerapan Surat Edaran Mahkamah Agung (SEMA) Nomor 04 Tahun 2010 menjadi tidak efektif. 


\section{2) Faktor Penegak hukum, yakni pihak-pihak yang membentuk maupun}

menerapkan hukum:

Pemanfaatan inkonsistensi aturan sebagaimana disebutkan diatas, oleh penegak hukum menjadi tujuan tersendiri demi kepentingannya sendiri atau kelompoknya. Adanya faktor X sebagaimana disebutkan dalam wawancara dengan narasumber diatas, faktor Penegak hukum dalam mengukur efektivitas hukum berjalan tidak efektif.

\section{3) Faktor sarana atau fasilitas yang mendukung penegakan hukum;}

Faktor sarana atau fasilitas yang mendukung dalam penerapan rehabilitasi narkotika di Kota Batam sudah lengkap, dengan adanya Loka Rehabilitasi narkotika, dimana Tim Asesmen Terpatu (TAT) yang sudah terbentuk dan telah mendapatkan sertifikati, maka faktor efektivitas hukum menurut faktor sarana dan prasarana, sangat efektif.

4) Faktor masyarakat, yakni lingkungan dimana hukum tersebut berlaku atau diterapkan;

Berkaitan dengan faktor masyarakat yang dibahas disini, diharapkan fungsi hukum sebagai sarana perubahan sosial, atau sarana merekayasa masyarakat ("social engineering") dapat menjadi kearah mana tujuan hukum tersebut diciptakan. Hukum merupakan sarana rekayasa masyarakat yang dikenal dengan istilah "a tool of social engineering", suatu istilah yang pertama dicetuskan oleh ahli hukum Amerika yang terkenal yaitu Roscou Pound. Roscoe Pound juga mengatakan bahwa "Law as a tool of social engineering" yang artinya Hukum adalah alat untuk memperbaharui atau merekayasa masyarakat. Secara sederhana, penulis berpendapat bahwa apa yang dimaksud oleh Roscoe Pound dengan "Law as a tool of social engineering" dapat diartikan bahwa Hukum diharapkan dapat mengarahkan perilaku masyarakat ke dalam apa yang menjadi tujuan hukum itu sendiri.

Rehabilitasi Narkotika merupakan momok yang memalukan (negatif) yang didengar di kalangan masyarakat, sehingga masyarakat cenderung menutupi apabila ada bagian keluarganya yang merupakan pecandu Narkotika. Hal ini dapat dilihat dari data yang didapatkan oleh peneliti, bahwa jumlah perkara Narkotika yang dilakukan proses hukum oleh penyidik Polda Kepri dan jumlah perkara yang masuk pada Pengadilan Negeri Batam masih banyak. Dan kemudian, sebagian dari masyarakat kita secara tidak langsung membiarkan adanya kegiatan peredaran gelap narkotika, sebagaimana telah diuraikan pada wawancara dengan salah satu penyelidik/penyidik pada Polresta Barelang sebagaimana terjadi di wilayah Kampung Aceh Kota Batam.

Berdasarkan uraian diatas, faktor masyarakat dalam mendukung berjalannya aturan terkait rehabilitasi Narkotika terhadap pecandu dan korban penyalahgunaan Narkotika, tidak dapat berjalan efektif.

5) Faktor kebudayaan, yakni sebagai hasil karya, cipta dan rasa yang didasarkan pada karsa manusia didalam pergaulan hidup. 
E.B Taylor yang dikutip oleh Koentjaraningrat, menerangkan bahwa kebudayaan adalah keseluruhan yang kompleks meliputi pengetahuan, kepercayaan, kesenian, moral, hukum, dan segala kecakapan, dan kebiasaan yang diperoleh manusia sebagai anggota masyarakat. Pengembangan kebudayaan adalah usaha manusia untuk menambah kebudayaan dari kondisi tertentu menuju pada kondisi kebudayaan yang lebih dapat memenuhi tuntutan kehidupannya. Tujuan pengembangan kebudayaan tersebut adalah agar manusia lebih memahami eksistensi dirinya ditengah alam, masyarakat, dan waktu, untuk kemudian melakukan evaluasi pemahaman tentang budayanya dan menetapkan strategi untuk menghadapi kondisi dan tantangan silih berganti. Sifat kebudayaan yang baik adalah dinamis, selalu dapat menyesuaikan diri dengan perkembangan masyarakat pelakunya. Perubahan Kebudayaan berpengaruh ke arah positif maupun negatif.

Kota Batam yang berbatasan langsung dengan negara tetangga seperti Singapura dan Malaysia, menyebabkan Batam menjadi multi kultural. Dengan pengaruh kebudayaan yang datang ke Kota Batam, dapat dilihat sebagai contoh, semakin banyaknya tempat hiburan malam di Kota Batam. Dengan semakin banyaknya tempat hiburan malam di Kota Batam, dapat dipastikan menjadi tempat yang rawan dalam peredaran gelap narkotika, dimana seseorang dapat dengan mudahnya menemukan barang-barang yang memabukkan termasuk Narkotika untuk dikonsumsi.

Dikaitkan dengan Teori efektivitas hukum, bahwa faktor kebudayaan dapat mempengaruhi tidak efektifnya aturan hukum.

\section{E. Kesimpulan}

Dari hasil penelitian yang didapatkan oleh peneliti, dapat diambil kesimpulan sebagai berikut :

Tata cara penerapan Rehabilitasi Narkotika terhadap pecandu dan korban penyalahgunaan Narkotika di Kota Batam dapat dilakukan melalui 2 (dua) cara :

1. Rehabilitasi Narkotika melalui Wajib Lapor (Sukarela/Voluntery).

Tata cara penerapan rehabilitasi narkotika melalui wajib lapor (Sukarela/Voluntery) telah diuraikan pada halaman 8 diatas.

Rehabilitasi Narkotika karena adanya Upaya Hukum (Compulsary).

Tata cara penerapan rehabilitasi narkotika melalui wajib lapor (Sukarela/Voluntery) telah diuraikan pada halaman 9-10 diatas.

2. Tidak ada kebijakan hukum yang dilakukan secara khusus yang dilakukan para pemangku jabatan di kota Batam untuk mengoptimalkan rehabilitasi terhadap pecandu dan korban penyalahgunaan Narkotika. 


\section{DAFTAR PUSTAKA}

\section{Buku}

Abdulkadir Muhammad, Hukum dan Penelitian Hukum, Bandung : PT. Citra Aditya Bakti, 2004

Achmad Ali, Menguak Teori Hukum (Legal Theory) dan Teori Peradilan (Judicialprudence) Termasuk Interpretasi Undang-Undang (Legisprudence), Jakarta: Penerbit Kencana, 2009

Bambang Sunggono, Metodologi Penelitian Hukum, Cet. 1, Jakarta : PT.Raja Grafindo Persada, 2007

Koentjaraningrat, Kebudayaan, Mentalitas dan Pembangunan, Jakarta : Gramedia Pustaka Utama, 1992

Lexy J Moleong, Metodologi Penelitian Kualitatif, Bandung: Remaja Rosda Karya, 2002

Munir Fuadi, Teori-Teori Besar (Grand Theory) Dalam Hukum, Jakarta: Kencana Prennamdeia Group, 2013

Peter Mahmud Marzuki, Penelitian Hukum, Cet.2, Jakarta : Kencana, 2008

Soerjono Soekanto, Pengantar Penelitian Hukum, Jakarta: UI Press, 1986

Syahruddin Nawawi, Penelitian Hukum Normative Versus Penelitian Hukum Empiris, Makassar: Umitoha Ukhuwah Grafika

\section{Artikel Jurnal}

Adi Purnomo, Fasilitas Pertukaran Budaya Indonesia -Jepang, Yogyakarta : UGM, 1995 


\section{Internet}

Institute For Criminal Justice Reform, Hakim Diminta Untuk Memberikan Putusan Rehabilitasi kepada Pengguna dan Pecandu Narkotika Sesuai SEMA 4/2010, 2017, Diambil pada 20 Juli 2018 dari https://icjr.or.id/hakim-diminta-untukmemberikan-putusan-rehabilitasi-kepada-pengguna-dan-pecandu-narkotikasesuai-sema-42010/

\section{Peraturan Perundang-Undangan}

Undang-undang Nomor 35 Tahun 2009 Tentang Narkotika (Lembaran Negara Tahun 2009 Nomor 143).

Peraturan Pemerintah Nomor 25 Tahun 2011 Tentang Pelaksanaan Wajib Lapor Pecandu Narkotika

Peraturan Kepala Badan Narkotika Nasional Nomor 11 Tahun 2014 Tentang Tata Cara Penanganan Tersangka Dan/Atau Terdakwa Pecandu Narkotika Dan Korban Penyalahgunaan Narkotika Ke Dalam Lembaga Rehabilitasi.

Peraturan Bersama antara Ketua Mahkamah Agung Republik Indonesia, Menteri Hukum dan Hak Asasi Manusia Republik Indonesia, Menteri Kesehatan Republik Indonesia, Menteri Sosial Republik Indonesia, Jaksa Agung Republik Indonesia, Kepala Kepolisian Negara Republik Indonesia, Kepala Badan Narkotika Nasional Republik Indonesia Tentang Penanganan Pecandu dan Korban Penyalahgunaan Narkotika ke Dalam Lembaga Rehabilitasi, Berita Negara Republik Indonesia Tahun 2014 Nomor 465.

Surat Edaran Mahkamah Agung RI Nomor 4 Tahun 2010 Tentang Penempatan Penyalahgunaan, Korban Penyalahgunaan Dan Pecandu Narkotika Ke Dalam Lembaga Rehabilitasi Medis Dan Rehabilitasi Sosial. 